Utah State University

DigitalCommons@USU

$11-1977$

\title{
Hypoxylon mammatum Pathotoxin Responsible for Canker Formation in Quaking Aspen
}

Arthur L. Schipper, Jr.

Follow this and additional works at: https://digitalcommons.usu.edu/aspen_bib

Part of the Agriculture Commons, Ecology and Evolutionary Biology Commons, Forest Sciences Commons, Genetics and Genomics Commons, and the Plant Sciences Commons

\section{Recommended Citation}

Schipper, Arthur L. 1977. Hypoxylon mammatum Pathotoxin Responsible for Canker Formation in Quaking Aspen 68: 866-872.

This Article is brought to you for free and open access by the Aspen Research at DigitalCommons@USU. It has been accepted for inclusion in Aspen Bibliography by an authorized administrator of DigitalCommons@USU. For more information, please contact

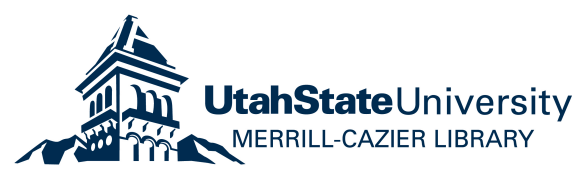




\title{
A Hypoxylon mammatum Pathotoxin Responsible for Canker Formation in Quaking Aspen
}

\author{
Arthur L. Schipper, Jr.
}

Principal Plant Physiologist, North Central Forest Experiment Station, U.S. Department of Agriculture. Fo Service, 1992 Folwell Avenue, St. Paul, MN 55108. Technical assistance was provided by Fannie M. Harne Biological Laboratory Technician, North Central Forest Experiment Station.

Mention of trade names does not constitute endorsement of the products by the U.S. Department of Agricultige Forest Service.

Accepted for publication 30 November 1977.

\section{ABSTRACT}

SCHIPPER. A. L., JR. 1978. A Hypoxylon mammatum pathotoxin responsible for canker formation in yuaking ance Phytopathology 68: 866-872.

A toxic substance produced by the fungus Hypoxylon mammatum was responsible for canker formation in quaking aspen (Populus tremuloides). Cell-free extracts of culture medium and cankered host tissue caused inhibition of wound callus formation, bark necrosis and collapse, and distal vein necrosis in aspen leaves. Twenty-three of $24 \mathrm{H}$. mammatum isolates and two other fungus species, Cenangium singulare and $H$. rubigosum, produced substances in culture that were toxic to aspen leaves. Twenty-seven plant species were tested by leaf assay for toxin sensitivity. Only $P$. tremuloides was highly sensitive to the $H$. mammatum toxin. Several other poplars. one willow species, and bur oak also gave weak positive reactions. The toxic substance has a molecular weight of between 700 and 1,100 daltons, is heat stable, is soluble in polar solvents, and can be partially purified either by gel filtration, silica gel column and thin-layer chromatography, or high-vaccuum sublimation.
Hypoxylon mammatum (Wahl.) Mill.causes a canker on quaking aspen (Populus tremuloides Michx.) that is characterized by a flattened, sunken surface with a noncallused yellow-orange margin. How H. mammatum induces canker formation is not clear. The fungus grows in the sapwood of infected trees and invades the bark from within $(9,11)$, but because aspen bark contains fungitoxic compounds (10), the fungus apparently only invades dead bark. Therefore, a toxin that kills aspen bark in advance of the fungus might be the agent that causes the bark necrosis symptom of the canker.

During field and greenhouse experiments, the first symptoms of $H$. mammatum infection observed on aspen were an inhibition of wound callus followed by collapse and subsequent necrosis of bark around inoculated wounds before the mycelium had advanced beyond the wounded area (12). Hubbes (9) found that dialyzable substances from $H$. mammatum agar cultures inhibited callus formation in wounds on aspen bark. Bagga and Smalley (4) found that culture filtrates and killed $H$. mammatum agar cultures could cause blackening of wounded or nonwounded aspen bark. Therefore, the possibility that $H$. mammatum produces a toxin that causes bark collapse and bark necrosis in aspen was investigated.

\section{MATERIALS AND METHODS}

Aspen bioassay.--Initially, an aqueous extract of $H$. mammatum rye grain culture medium was prepared by soaking the grain in two parts $(\mathrm{w} / \mathrm{v})$ distilled water for 16

00032-949X/78/000148\$03.00/0

Copyright (c) 1978 The American Phytopathological Society, 3340

Pilot Knob Road, St. Paul, MN 55121. All rights reserved. $\mathrm{hr}$ and then filtering it through a Millipore filter $(0.22 \mu \mathrm{m}$ pore size) (Millipore Corp., Bedford, MA 01730) to sterilize the extract. In subsequent experiments, the rye grain culture medium was homogenized in acetone with a Waring Blendor (Waring Prod. Div., Dynamics Corporation of America, New Hartford, CT 06057) for 5 min, the brei was stirred for $1 \mathrm{hr}$; and then filtered through Celite 545 (Johns-Manville, P.O. Box 5108, Denver, Co 80217). The acetone was removed by vacuum evaporation and the residue was dissolved in distilled water; insoluble materials were removed by filtration.

Stem wound bioassay.-Twenty greenhouse-grown aspen seedlings (104 $\pm 2 \mathrm{~cm}$ tall) (grown from seed collected from trees in Minnesota with $H$. mammatum cankers) were placed in a growth chamber [ $16 \mathrm{hr}$ day $(12,900$ lux $)$ at $24 \mathrm{C}, 8 \mathrm{hr}$ night at $18 \mathrm{C}]$. After removing all leaves from the basal $60-\mathrm{cm}$ of each stem, rubber septum vial stoppers were placed around each stem at 15,30,45. and $60 \mathrm{~cm}$ above the soil and made watertight with RTV. 11 silicone rubber (General Electric Company, Silicone Products Div., Waterford, NY 12188) to form reservoirs that held $1.5 \mathrm{ml}(8)$. Two randomly chosen reservoirs on each stem were filled with the test extract and the other two reservoirs were filled with the control extract from sterile rye grain. After the reservoirs were filled, a $0.5-\mathrm{cm}$ slit was made with a scalpel on the aspen stem below the surface of the extract in the reservoir. The extract in each reservoir was replenished as needed to keep the wounds submerged. The reservoirs were removed and the wounds examined after 4 days and again 3 and 7 days later. The experiment was repeated four times. Five additional trees were treated with the same extracts, but without wounding.

Aspen leaf bioassay.-Fully-expanded young aspen leaves were placed in $27-\mathrm{ml}$ vials that contained $2 \mathrm{ml}$ of 
toxin or control extract (enough to immerse the cut end of the petiole). Sixteen, 24, 48, 72, and $96 \mathrm{hr}$ later the leaves were examined for vein necrosis. Leaves of various poplar and other plant species also were treated as described in the aspen leaf bioassay.

Impure freeze-dried extract that contained toxin was added to aspen leaf assay vials in concentrations ranging from $40 \mathrm{mg}$ to $4 \times 10^{-6} \mathrm{mg} / \mathrm{ml}$ distilled water. Aspen leaves placed in these solutions were examined as before.

Cut stem assay.--Aspen stem segments, $5 \mathrm{~cm}$ long $(0.3$ to $0.5 \mathrm{~cm}$ diameter), were placed in $27-\mathrm{ml}$ vials that contained $2 \mathrm{ml}$ of the toxin or control extract. The egments were examined daily for 7 days for signs of bark necrosis. In addition, some segments were removed from toxin and control extracts daily and allowed to dry to determine the effects of desiccation on toxin activity.

Sensitivity to toxin.- In addition to aspen, leaves from the following species were used to determine their susceptibility to the toxin substance: Acer negundo L. (box elder), Berberis vulgaris L. (European barberry), Chenopodium album L. (goosefoot), Cirsium arvense (L.) Scop. (Canada thistle), Glycine max (L.) Merr. (soybean), Juglans nigra L. (black walnut), Lycopersicon esculentum Mill. (tomato), Malus sylvestris Mill. (apple), Phaseolus vulgaris L. (kidney bean), Picea glauca (Moench) Voss (white spruce), Poa pratensis L. Kentucky blue grass), Populus alba var. pyramidalis Bunge (Bolleana poplar), P. balsamifera Muench. (balsam poplar), $P$. deltoides Marsh. (cottonwood), $P$. grandidentata Michx. (big-toothed aspen), Prunus virginiana L. (choke cherry), Quercus macrocarpa Michx. (bur oak), Rhus grabra L. (sumac), Ribes sativum Syne (currant), Salix spp. (willow), Sambucus canadensis $\mathrm{L}$ (common elder), Syringa vulgaris L. (common lilac), Toxus canadensis Marsh. (Canada yew), Tilia americana L(basswood), and Ulmus americana L. (American elm).

Toxin production by Hypoxylon mammatum and other fungal genera.-Twenty-four isolates of $H$. mammatum, obtained from ascospores and from cankers collected throughout the Lake States and North Dakota, were used (Table 1) (1). Fourteen other fungi also were
TABLE 1. Toxin production by Hypoxylon mammatum isolates from the north-central region of the USA

\begin{tabular}{|c|c|c|c|}
\hline \multirow{2}{*}{ Location $^{3}$} & \multirow{2}{*}{$\begin{array}{l}\text { H. mammatum } \\
\text { isolate no. }\end{array}$} & \multicolumn{2}{|c|}{ Aspen leaf bioassay reaction } \\
\hline & & $24 \mathrm{hr}$ & $48 \mathrm{hr}$ \\
\hline \multirow[t]{3}{*}{ North Dakota } & $1-1$ & +0.5 & +1.4 \\
\hline & $1-2$ & - & +0.3 \\
\hline & $1-3$ & - & +0.2 \\
\hline \multirow[t]{8}{*}{ Minnesota } & $2-4$ & +2.0 & +3.0 \\
\hline & $2-5$ & +0.1 & +0.8 \\
\hline & $2-6$ & +1.1 & +2.1 \\
\hline & $3-7$ & +0.3 & +1.9 \\
\hline & $3-8$ & +0.1 & +1.0 \\
\hline & $3-9$ & +0.7 & +2.8 \\
\hline & $4-10$ & +0.7 & +1.5 \\
\hline & $4-11$ & +0.1 & +1.3 \\
\hline \multirow[t]{5}{*}{ Wisconsin } & $5-12$ & +0.1 & +0.6 \\
\hline & $5-13$ & - & - \\
\hline & $5-14$ & +0.1 & +1.0 \\
\hline & $6-15$ & - & +0.8 \\
\hline & $6-16$ & +0.1 & +1.6 \\
\hline \multirow[t]{6}{*}{ Michigan } & $7-17$ & +0.3 & +1.1 \\
\hline & $7-18$ & +0.6 & +2.3 \\
\hline & $7-19$ & +0.5 & +1.5 \\
\hline & $8-20$ & +0.5 & +2.0 \\
\hline & $8-21$ & +0.5 & +1.0 \\
\hline & $8-22$ & - & +0.4 \\
\hline NC-68 & 23 & +0.1 & +1.0 \\
\hline Conidial & 24 & - & +0.1 \\
\hline
\end{tabular}

${ }^{a}$ Locations and isolate numbers refer to those used in Anderson and Schipper. 1975. Eur. J. For. Pathol. 5:216-224.

${ }^{\mathrm{b}}$ Aspen leaf bioassay for $H$. mammatum toxin: minus (-) indicates no toxin reaction; plus $(+)$ refers to a positive toxin reaction. The associated number refers to amount of leaf blade necrosis where $1=25 \%, 2=50 \%, 3=75 \%$, and $4=100 \%$.

TABLE 2. Toxin production by various fungi that cause tree cankers

\begin{tabular}{|c|c|c|}
\hline Fungus & Isolated from & $\begin{array}{c}\text { Aspen leaf } \\
\text { assay }\end{array}$ \\
\hline 4)poxylon mammatum (Wahl.) Mill. & Ascospores (Minnesota) & $+3.7^{\mathrm{a}}$ \\
\hline Cenangium singulare (Rehm.) Davids. & Aspen canker (Colorado) & +3.3 \\
\hline Ceratocystis crassivaginata Griffin & Aspen canker (Minnesota) & +1.0 \\
\hline C. fipbriata Ell. \& Halst. & Aspen canker (Minnesota) & - \\
\hline Cilifera (Fr.) C. Mor. & Aspen canker (Colorado) & +0.4 \\
\hline C.pulina Hinds \& Davids. & Aspen canker (Colorado) & +0.2 \\
\hline Diaporthe allegheniensis R. H. Arn. & Yellow birch canker (Michigan) & - \\
\hline Endothia parasitica (Murr.) And. \& And. & American chestnut canker & +0.5 \\
\hline Hypoxylon rubigosum Pers. ex Fr. & Sugar maple canker (Michigan) & +1.2 \\
\hline Fectria gallagania Bres. & Aspen canker (Minnesota) & +0.7 \\
\hline Shizophyllum commune Fr. & Sporophore (Minnesota) & - \\
\hline Ceratocystis tremulo-aurea & Aspen canker (Minnesota) & +0.7 \\
\hline C. tremulo-aurea & Aspen canker (Colorado) & +0.5 \\
\hline Valsa ambiens & Ŷellow birch canker (Michigan) & - \\
\hline
\end{tabular}

'Aspen leaf bioassay for toxin production by tree-cankering pathogenic fungi: (a positive leaf assay means distal vein necrosis was

mesent) $1=0$ of leaf blade necrotic; $3=$ up to $75 \%$ of leaf blade necrotic; and $4=$ up to

tao of leaf blade necrotic (a negative assay means that no distal vein necrosis was present). 
tested (Table 2). Extracts of these fungi were prepared by acetone extraction of cultures grown on rye grain.

Isolation of toxin from cankers.-Extracts from healthy and Hypoxylon-cankered aspen trees and from H. mammatum perithecial stroma were prepared by acetone extraction of air-dried bark, wood, and stroma, that had been ground to pass a $0.97-\mathrm{mm}$ (20-mesh) screen in a Wiley mill (A. H. Thomas Company, P.O. Box 779, Philadelphia, PA 19105), then extracted with acetone as described previously. After the acetone was removed by vacuum evaporation, the water-soluble components of the extracts were tested for the toxic substance by the aspen leaf bioassay.

Toxin production in culture-Hypoxylon mammatum was grown in $250 \mathrm{ml}$ of aspen powder in distilled water $(1: 100, w / v)$, glucose-peptone in water $(1: 1: 100, w / w / v)$, malt extract in water $(2: 100, w / v)$, or potato extract in water $(2: 100, \mathrm{w} / \mathrm{v})$ in diffuse light at 25 C. At 1-wk intervals mycelium was recovered by filtration. Each culture filtrate was treated with acetone to remove proteins, evaporated under vacuum to near dryness, diluted to $50 \mathrm{ml}$ with water, and tested for toxic activity by the aspen leaf bioassay. The 5-fold concentration was used in order to detect the toxin soon after its production began. At later intervals the toxin could be detected in unconcentrated filtrates.

The mycelium was homogenized in acetone, then removed by filtration. The extract was freed of acetone by vacuum evaporation, dissolved in $5 \mathrm{ml}$ of water, and tested for toxic activity by the aspen leaf bioassay.

Partial purification of toxin.-Several alternative methods were used to partially purify the toxic extract. Column chromatography of $H$. mammatum rye grain extracts was done with Sephadex G-10, G-15, and G-25 (Pharmacia Fine Chemicals, Div. Pharmacia Inc., Piscataway, NJ 08854) and Bio-gel P-2 (Bio-Rad Laboratories, Richmond, CA 94804), with distilled water or $0.1 \mathrm{M}$ phosphate buffer $(\mathrm{pH} \mathrm{7})$ as the eluant. Fifty to $1003-\mathrm{ml}$ fractions, depending on the gel filtration medium used, were collected and tested for toxic activity with the aspen leaf bioassay. Toxin in a minimum volume of acetone was applied to a silica gel column and eluted with $60 \%$ petroleum ether (b.p. $60-70$ C): $40 \%$ isopropyl alcohol. One-hundred-forty $5-\mathrm{ml}$ fractions were collected, evaporated under vacuum to dryness, redissolved in an equal volume of water, and tested by the aspen leaf bioassay for toxic activity.

Extract dissolved in acetone was separated by thinlayer chromatography (TLC) with a variety of solvents (Fig. 5). After development was complete, plates were examined under an ultraviolet lamp and fluorescent bands were marked. Then each fluorescent and nonfluorescent portion was scraped separately from each plate, eluted with acetone, dried in vacuo, and redissolved in $5 \mathrm{ml}$ water. Each fraction obtained in this manner was checked for toxic activity by the aspen leaf bioassay.

Extract dissolved in water was applied to a mixed-bed ion exchange resin column of Amberlite IR-400 and IRA120 (Rhom and Haas Company, Philadelphia, PA 19105), and eluted with $200 \mathrm{ml}$ distilled water and then with $200 \mathrm{ml}$ of $1 \mathrm{M}\left(\mathrm{NH}_{4}\right)_{2} \mathrm{CO}_{3}$. The water fraction was evaporated under vacuum to near dryness and then diluted to the original volume of applied toxin. The ammonium carbonate fraction was heated on a steam bath until the ammonium carbonate was removed, the evaporated under vacuum to near dryness and diluted the original volume. Each fraction was tested for toxi activity by the aspen leaf bioassay.

Additonal purification of the toxin was attempted high-vacuum sublimation. Toxin prepared by aceton extraction from rye grain culture was evaporated to ne dryness, placed in a sublimation chamber, then air-dried Pressures below $1 \times 10^{-6}$ Torr were obtained and the sublimation chamber was partially immersed in an o bath heated to $65,110,160$, and $180 \mathrm{C}$, and held at eact temperature for $0.5 \mathrm{hr}$. The sublimate was dissolved is acetone at the end of each heating period. Each eluate and the residue from the $180 \mathrm{C}$ treatment was evaporated i vacuo to remove acetone, dissolved in water, and tested for toxic activity by the aspen leaf bioassay.

\section{RESULTS}

Aspen bioassay.-Bark collapse and bark necrosis (Fig. 1) were found on $76 \%$ of the wounds treated with the H. mammatum rye grain extract (Table 3), callus formed

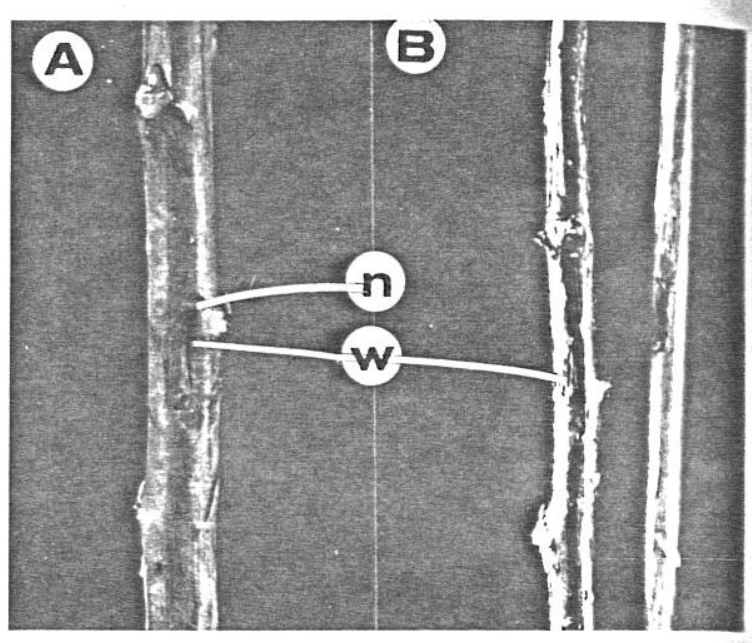

Fig. 1-(A, B). A) Aspen stem with a 0.5-cm-long wound treated with the Hypoxylon mammatum pathotoxin. Note the absence of callus in the wound and the discolored area of necrotic bark surrounding the wound. B) A 0.5 -cm-long wound on a similar aspen stem treated with the control extract. Note the wound callus within the wound and the absence of discoloration and necrosis surrounding the wound ( $w=$ wound: $n=$ necrotic bark).

TABLE 3. Effect of Hypoxylon mammatum rye grain culture extracts and control extracts on wounded aspen bark

\begin{tabular}{lccc}
\hline \hline \multirow{2}{*}{ Treatment $^{\mathrm{a}}$} & \multicolumn{3}{c}{ Host response } \\
\cline { 2 - 4 } & $\begin{array}{c}\text { Bark } \\
\text { necrosis }\end{array}$ & $\begin{array}{c}\text { Wound } \\
\text { callus } \\
(\%)\end{array}$ & $\begin{array}{c}\text { No } \\
\text { reaction }\end{array}$ \\
\hline H. mammatum extract & 76 & 2 & $(5)$ \\
Sterile rye extract & 0 & 93 & 7 \\
\hline
\end{tabular}

${ }^{\text {a }}$ Treatment was applied in reservoirs to 80 trees for 4 days and observations were made after 7 additional days. 
on $2 \%$ of the wounds, and no reaction was evident on $22 \%$ of the wounds. Wound callus developed on $93 \%$ of the wounds treated with extract of sterile rye grain. None of the control wounds developed bark collapse or bark necrosis. In control wounds, callus development was first visible 3 days after treatment as a yellow-white line in the wound, but in toxin-treated wounds the edge of the wound was black. Bark necrosis was evident around the wounds before the reservoirs were removed. Bark collapse was observed 3 days after reservoirs were removed and increased during the following week, but did not increase further. Bark collapse or necrosis did not develop on trees where reservoirs received toxin but no
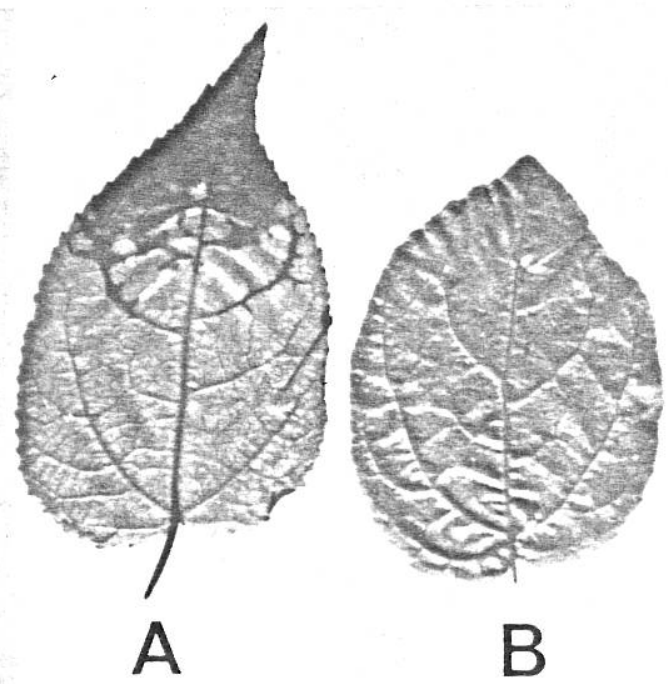

Fig. 2-(A, B). Aspen leaves treated in the aspen leaf bioassay for Hypoxylon mammatum toxin. Leaf $\mathbf{A}$ ) was treated with a loxin-containing extract; leaf B) was treated with a control extract that did not contain any toxin. Note the distinctive aecrosis on the toxin-treated leaf. The necrosis begins in veins as an be seen in some of the lower veins in the leaf, then spreads into the interveinal regions of the leaf blade. wound was made.

When whole aspen leaves were placed in a $27-\mathrm{ml}$ vial with a few milliliters of toxin-containing extract so that the petiole alone was immersed, vein necrosis at the distal end of the leaf appeared within $7 \mathrm{hr}$ and spread over much of the leaf blade within $16 \mathrm{hr}$ (Fig. 2). When the chemicals used to prepare the extracts as well as with extracts of sterile rye grain, were tested, either no leaf necrosis occurred or it occurred at the basal end of the leaf.

In the aspen stem segment bioassay, so long as the cuttings were left in the vials, only slight discoloration appeared at the base of the cuttings. However, within a few hours after the cuttings were removed from the vial and laid on filter paper, long, irregular areas of black necrosis and collapse appeared which extended from the base toward the apex of the cutting. Necrosis did not appear on cuttings exposed only to extracts from sterile rye grain or to distilled water.

Toxic activity was evident within $24 \mathrm{hr}$ in the assays that contained from $40 \mathrm{mg}$ to $2 \mathrm{mg} / \mathrm{ml}$ of impure extract. Leaves exposed to $4 \times 10^{-3} \mathrm{mg}$ per $\mathrm{ml}$ extract required 96 hr to develop necrosis.

Seven of the 27 plants tested (Table 4) were sensitive to the toxin, but only two of these were not species of Populus. In all cases, leaves of quaking aspen were more sensitive than any other plant species. Vein necrosis developed in $16 \mathrm{hr}$ in quaking aspen leaves but developed more slowly in the other species.

Production of toxic substances by Hypoxylon mammatum and other genera.-Only one of the $H$. mammatum isolates did not produce detectable toxin as measured by the aspen leaf bioassay (Table 3 ). The 23 isolates that produced the toxic substance differed in the amount they produced: only five produced enough to make between 50 and $75 \%$ of the leaf blade necrotic. An isolate from a canker obtained near Baudette in northern Minnesota produced more toxin than any of the others. A conidial isolate that was nonpathogenic produced only barely detectable amounts of toxin. The one isolate that did not produce detectable toxin had been pathogenic in inoculation trials conducted earlier, but may have lost pathogenicity during culture.

In a separate experiment 14 isolates, including $H$.

TABLE 4. Susceptibility of various plant species to the Hypoxylon mammatum pathotoxin

\begin{tabular}{|c|c|c|c|}
\hline \multirow{2}{*}{ Plant family/species } & \multirow{2}{*}{ Common name } & \multicolumn{2}{|c|}{ Leaf assay reaction } \\
\hline & & Toxin & Control \\
\hline \multicolumn{4}{|l|}{ Salicaceaer } \\
\hline Populus alba var. pyramidalis & Bolleana poplar & $+1^{\mathrm{a}}$ & $-{ }^{\mathrm{b}}$ \\
\hline P. balsamifera & Balsam poplar & +2 & - \\
\hline P. deltoides & Eastern cottonwood & +1 & - \\
\hline P. grandidentata & Bigtooth aspen & +2 & - \\
\hline P. tremuloides & Quaking aspen & +4 & - \\
\hline Salix sp. no. 1 & Willow & +1 & - \\
\hline Salix sp. no. 2 & Willow & - & - \\
\hline \multicolumn{4}{|l|}{ Fagaceae. } \\
\hline Quercus macrocarpa & Bur oak & +1 & - \\
\hline
\end{tabular}

'A positive leaf assay means distal vein necrosis was present. $1=$ up to $25 \%$ of leaf blade necrotic; $2=u p$ to $50 \%$ of leaf blade

necrotic; $3=$ up to $75 \%$ of leaf blade necrotic; and $4=$ up to $100 \%$ of leaf blade necrotic.

A negative assay means that no distal vein necrosis was present. 
mammatum, were grown in rye grain culture and tested for toxin production by the aspen leaf bioassay method (Table 2). Only two of the isolates, H. mammatum and Cenangium singulare, produced large amounts of toxin. Chromatography (TLC) of both the H. mammatum toxin and the $C$. singulare toxin indicated that the two toxins migrated in an almost identical manner on TLC plates. Cenangium singulare is an important canker-causing pathogen of quaking aspen in Colorado. Ceratocystis crassivaginata and $H$. rubigosum both produced material in culture that gave positive reactions in the aspen leaf bioassay. Ceratocystis pilifera, $C$. populina, $C$. tremmulo-aurea, Endothia parasitica, and Nectria gallagania also produced detectable amounts of toxic material but the leaf assay reactions required 72 to $96 \mathrm{hr}$ and were not identical with the reaction for the toxic substances from $H$. mammatum and Cenangium singulare.

Isolation of toxic substance from cankers.-Toxic materials were obtained from extracts prepared from perithecial stroma, from bark and wood within cankers, and from bark and wood in the $5 \mathrm{~cm}$ zone adjacent to cankers. Toxic activity was not detected in tissue obtained further away from the cankers or from tissue obtained from healthy trees. Ascospore extracts did not yield the toxic substance.

Toxic substance production in culture.-Small amounts of toxic activity could be detected in the culture filtrate after the first week of H. mammatum growth, and the titer of toxic activity increased in culture filtrates obtained after longer times. No toxic activity could be detected in extracts prepared from mycelium removed from the liquid medium.

In a separate experiment, liquid cultures consisting either of aspen wood powder suspension, glucosepeptone, or potato extract were compared with malt extract as media for toxic substance production. Extracts from the aspen powder suspension contained the most toxic substance, glucose-peptone and malt extract were intermediate, and potato extract was a poor medium for toxic substance production.

Isolation and partial purification of the toxic substances.-When extracts from rye grain culture of $H$. mammatum were eluted through Sephadex G-10, G-15, G-25, or Bio-gel P-2, toxic activity was detected as a major peak with a shoulder (Fig. 3). Results from both buffered and nonbuffered runs were identical, but buffer caused basal damage to leaves. The elution pattern of the toxin on Bio-gel P-2 was compared with that of raffinose, sucrose, and glucose. The toxin eluted between the void volume and raffinose, indicating that the molecular weight of the toxin was between 594 and 1,800 daltons, the exclusion limit of Bio-gel P-2 listed by the Bio-Rad Laboratories. Toxic fractions of $H$. mammatum toxin eluted through Bio-gel P-2 were pooled, dried, and analyzed by direct probe on a LKB mass spectrometer (Type 9000, LKB Produkter, Bromma 1, Sweden). Although the toxin preparations contained other compounds in addition to the toxic substance, and the mass of the highest-molecular-weight compound varied between preparations, none of the components found in the toxin preparations had a molecular ion with a mass higher than 1,100 .

When toxin was separated on silica gel columns and petroleum ether-isopropyl alcohol $(6 / 4, v / v)$ was the eluant, multiple peaks of toxic activity were detected b the aspen leaf bioassay (Fig. 4). These fractions of toxi activity appeared to correspond with toxin activity detected by TLC (Fig. 5). With TLC, however, great had to be taken to remove all silica gel from the extrac because silica gel caused necrotic flecks in aspen leave The toxic activity sublimed only between 65 and $110 \mathrm{C}$ Chromatography (TLC) of the toxic sublimate showe that it contained a number of components, some of which were not toxic.

When toxin was eluted through a column of Amberlit IR-400 or IRA-120, all of the toxic activity was recoveret in the water eluate. No toxin activity was detected in the ammonium carbonate eluate of resin.

\section{DISCUSSION}

Although several bioassay systems were tried, only the aspen stem wound bioassay, the aspen stem segment bioassay, and the aspen leaf bioassay were useful to detect the $H$. mammatum toxic substance. The aspen leat bioassay was the simplest of the three; it required the fewest plants, and easily could be used to test a large number of samples for toxin. The toxic action in both the

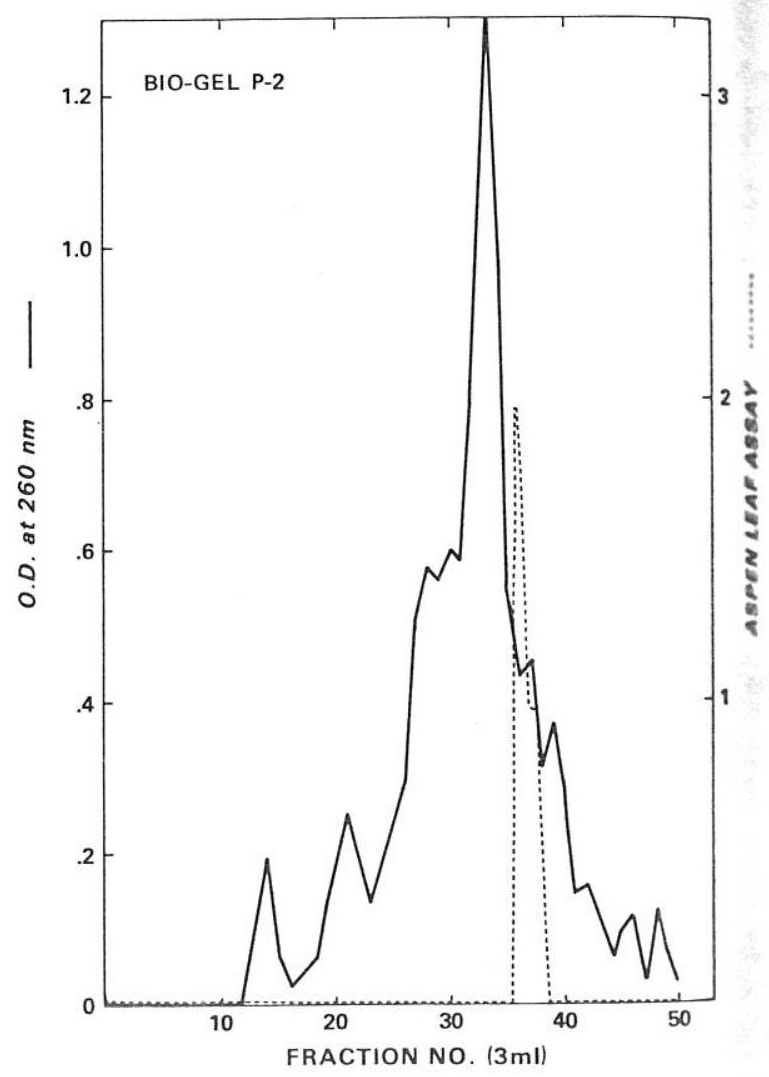

Fig. 3. Chromatogram (Bio-gel P-2) of the Hypoxylos mammatum toxin. Essentially all of the activity was contained a single peak that eluted after most of the 260 -nm-adsorbin material in the extract. 
sspen leaves and in aspen stem cuttings was highly sensitive to moisture regime of the tissue. Thus, toxin was zaken up by the leaf but the necrotic response to the toxin was delayed until leaf transpiration caused the leaf to be under moisture stress. In addition, bark necrosis on the stem segments treated with toxin did not appear until after the segment had been allowed to partially dry. Bier (6) and Bagga and Smalley (3) reported that $H$. mammatum cankers develop most rapidly when moisture is low in the bark of inoculated plants.

The aspen stem segment bioassay showed that the leaf vein necrosis probably was caused by the same toxic substances that caused stem bark necrosis and collapse. When left in sterile solutions for extended time periods, aspen stem segments developed basal callus but such callus did not develop on cuttings placed in solutions that were toxic in aspen leaf bioassays. Thus the toxic substances that cause vein necrosis and bark necrosis were probably the same as those that inhibited wound callus in intact trees inoculated with $H$. mammatum.

The toxin may be associated closely with pathogenicity. H. mammatum is primarily a pathogen of quaking aspen, although it has been reported on other species in a parasitic or saprophytic role $(2,5,7)$. On most species, wounds inoculated with $H$. mammatum rapidly develop callus and no infection occurs. These species also are not sensitive to the H. mammatum toxin (Table 4). Of the species showing sensitivity to the toxin, only $P$. tremuloides was highly sensitive; all other Populus spp. tested were only slightly sensitive. These same Populus spp. were inoculated with $H$. mammatum (5) and were found to be immune or only slightly susceptible to infection and canker development. On some of the species, a canker began to develop, but then healed over.
Of the 14 isolates of various fungi that were tested, only two, H. mammatum and Cenangium singulare, produced positive necrotic reactions in the aspen leaf bioassay. The $C$. singulare extract produced a reaction that could not be distinguished from that produced by the H. mammatum extracts.

Detection of the toxic activity in cankered portions of quaking aspen trees and in the regions immediately adjacent to cankers indicates that the toxin may produce the canker symptoms caused by $H$. mammatum. Although large amounts could be detected within the canker, the toxin reaction was weaker in the 5 -cm portion of bark and wood surrounding the canker. Therefore, the toxin must only act near where it is produced and released by the fungus mycelium. This observation could explain why the symptoms of H. mammatum infection is a limited necrosis rather than a long necrotic streak such as might occur if the toxin was readily translocated.

Experiments with $H$. mammatum grown in liquid culture show that the toxin is excreted rapidly from the mycelium of the fungus; however, none can be demonstrated in extracts of mycelium. Because the toxin could be demonstrated in cankered host tissue as well as in culture and because the amounts in culture increased with time, the toxin evidently is a regular metabolic product of $H$. mammatum growth rather than a material produced in response to the host.

Gel-filtration experiments indicated that the toxin is a molecule or group of molecules with an approximate molecular weight between 600 and 1,800. The molecular weight of the parent ions of all components detected by mass spectrometry was 1,100 or less. Further experimentation with both silica gel column chromatography and TLC indicated that the toxin might

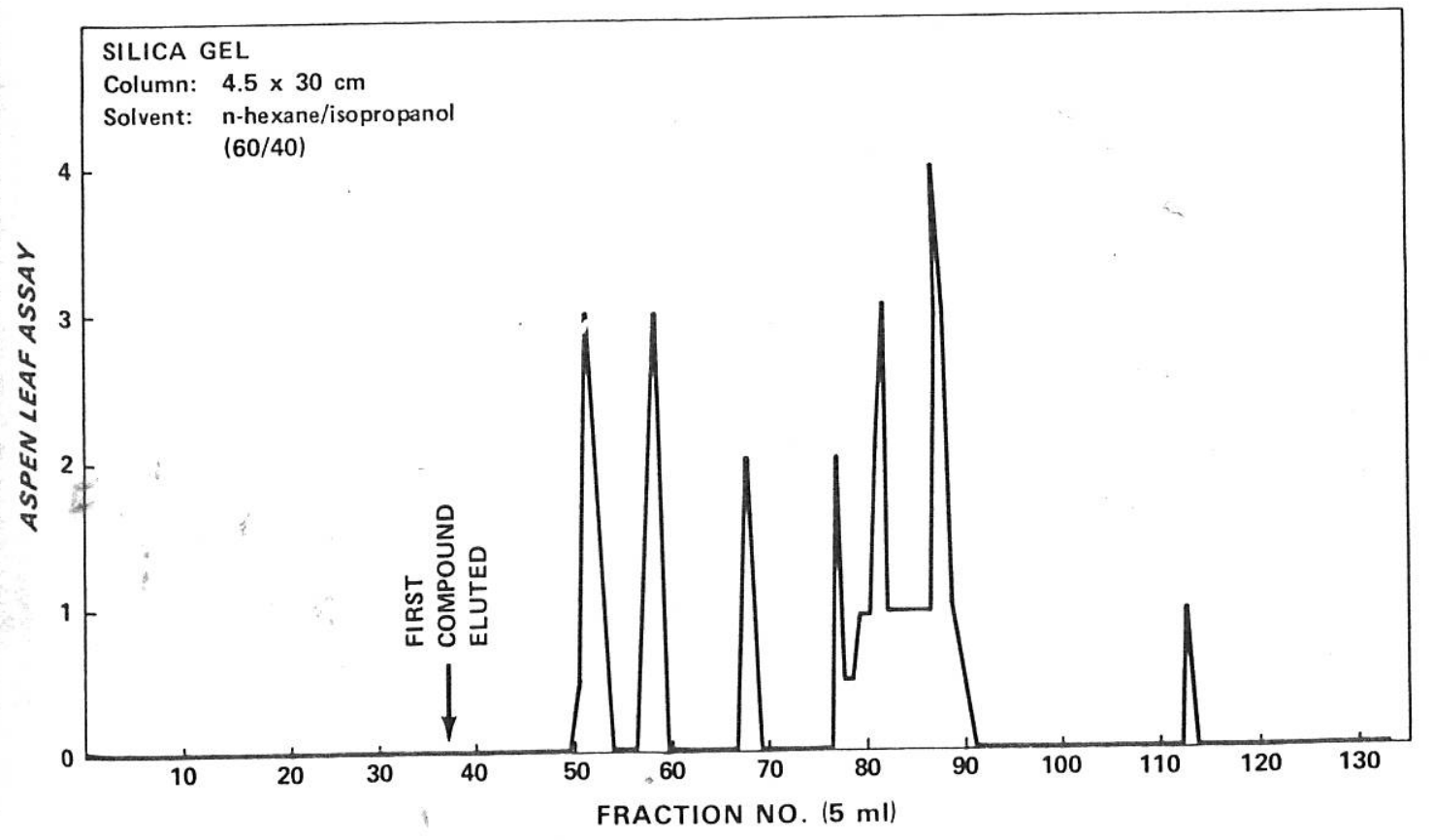

Fig. 4. Silica-gel chromatography of Hypoxylon mammatum toxin. The arrow indicates the point at which the first material detectable at $260 \mathrm{~nm}$ was eluted. Each fraction was assayed by the aspen leaf bioassay technique. 


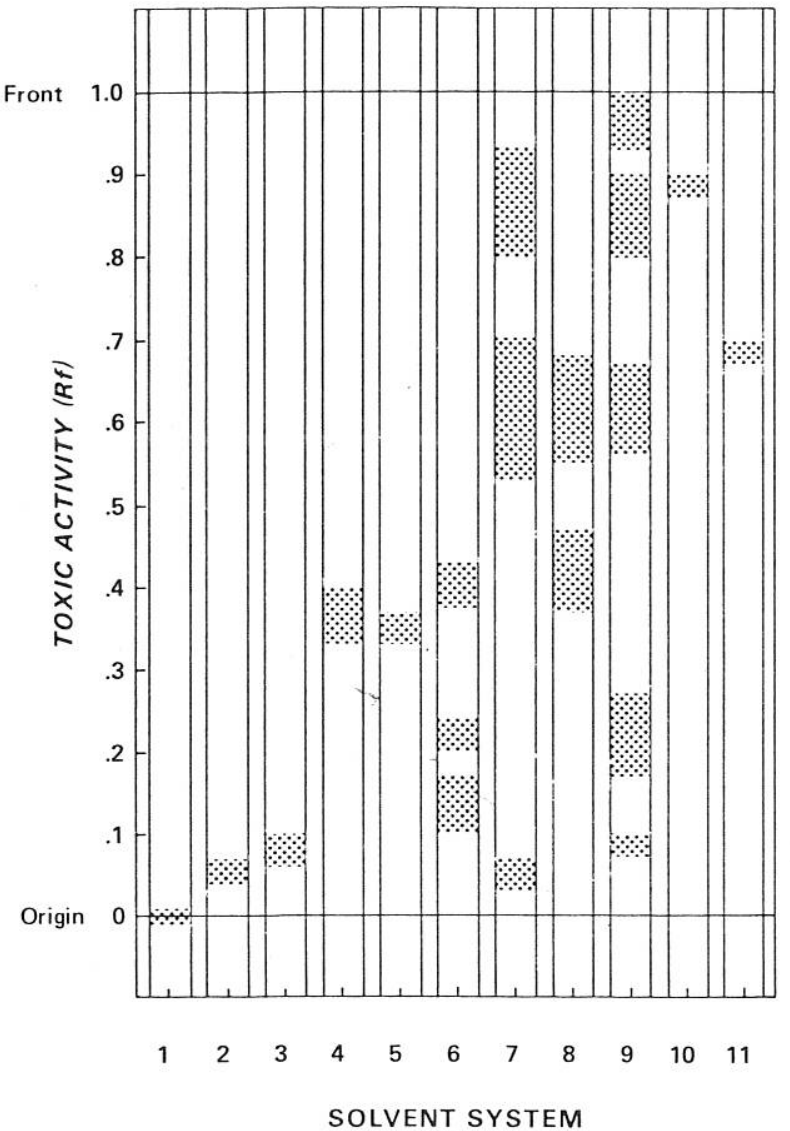

Fig. 5. Diagrammatic representation of thin-layer chromatograms of the toxins extracted from Hypoxylon mammatum cultures. Toxic activity in water eluates of the chromatograms are shown by shaded portions of the diagrams. The solvent or mixtures $(\mathrm{v} / \mathrm{v})$ used were: 1. toluene; 2. chloroform/methanol (99/1); 3. chloroform/acetone $(90 / 10) ; 4$. chloroform/ethanol $(80 / 20)$; 5. chloroform/methanol/acetic acid (67/16.5/16.5); 6. benzene/ethanol $(80 / 20)$; 7 . ethyl acetate; 8 . ethyl acetate/acetone $(90 / 10) ; 9$. benzene/ethanol/acetic acid (67/16.5/16.5); 10. benzene/methanol/acetic acid (79/14/17); 11. ethanol/water/boric acid/acetic acid (70/26/3/2). consist of as many as seven components.

Toxin activity was detected in a whitish material that sublimed at a temperature between $65 \mathrm{C}$ and $110 \mathrm{C}$. $\mathrm{N}_{0}$ attempt was made to determine at which temperature in that range the toxin sublimed. Because the toxis substance is highly soluble in acetone, water, and alcohols, it appears that it is a hydroxylated compound of group of compounds. The toxic substance is not solube in nonpolar solvents such as chloroform, ether, or hexane. In other experiments the toxic substance in crud extract was found to be heat-stable up to at least $121 \mathrm{C}$

\section{LITERATURE CITED}

I. ANDERSON, F. W., and A. L. SCHIPPER, JR. 1975 Variation among isolates of Hypoxylon mammatum Eur. J. For. Pathol. 5:216-224.

2. ANDERSON, R. L., and G. W. ANDERSON. $196 \%$ Hypoxylon canker of aspen. U.S. Dep. Agric., For. Serv For. Pest Leafl. 6. 6 p. + illus.

3. BAGGA, D. K., and E. B. SMALLEY. 1967. Water stress in relation to initiation and development of Hypoxyloe canker of aspen. Phytopathology 57:802.

4. BAGGA, D. K., and E. B. SMALLEY. 1974. The development of Hypoxylon canker of Populus tremuloides: role of ascospores, conidia, and toxins. Phytopathology 64:654-658.

5. BERBEE, J. G., and J. D. ROGERS. 1963. Life cycle and host range of Hypoxylon pruinatum and its pathogenesis on poplars. Phytopathology 54:257-261.

6. BIER, J. E. 1964. The relation of some bark factors to canker susceptibility. Phytopathology 54:250-253.

7. FRENCH, D. W., C. S. HODGES, JR., and J. D. FROYD 1969. Pathogenicity and taxonomy of Hypoxylon mammatum. Can. J. Bot. 47:223-226.

8. FREFORY, F. F. 1969. A technique for inoculating plants with vascular pathogens. Phytopathology 59:1014.

9. HUBBES, M. 1964. The invasion site of Hypoxylon pruinatum in Populus tremuloides. Phytopathologs 54:896.

10. HUBBES, M. 1966. Inhibition of Hypoxylon pruinatum (Klotzsche) Cke. by aspen bark meal and nature of active extractives. Can. J. Bot. 44:365-386.

11. SCHIPPER, A. L., JR. 1971. Alteration of sugar translocation in aspen by Hypoxylon mammatum. Phytopathology 61:366-368.

12. SCHIPPER, A. L., JR. 1975. Changes in dehydrogenase and peroxidase activities of aspen infected with Hypoxylon mammatum. Phytopathology 65:440-445. 